\title{
GRAFIK PENGENDALI MIXED EXPONENTIALLY WEIGHTED MOVING AVERAGE - CUMULATIVE SUM (MEC) DALAM ANALISIS PENGAWASAN PROSES PRODUKSI (Studi Kas us : Wingko Babat Cap "Moel”)
}

\author{
Aulia Resti ${ }^{*}$, Tatik Widiharih ${ }^{2}$, Rukun Santoso ${ }^{3}$ \\ 1,2,3 Departemen Statistika, Fakultas Sains dan Matematika, Universitas Diponegoro \\ *email: auliaresti24@gmail.com
}

\begin{abstract}
Quality control is an importantrole in indus try for maintain quality stability. Statistical process control can quickly investigate the occurrence of unforeseen causes or process shifts using control charts. Mixed Exponentially Weighted Moving Average - Cumulative Sum (MEC) control chart is a tool used to monitor and evaluate whether the production process is in control or not. The MEC control chart method is a combination of the Exponentially Weighted Moving Average (EWMA) and Cumulative Sum (CUSUM) charts. Combining the two charts aims to increase the sensitivity of the control chart in detecting out of control. To compare the sensitivity level of the EWMA, CUSUM, and MEC methods, the Average Run Length (ARL) was used. From the comparis on of ARL values, the MEC chart is the most sens itive control chart in detecting out of control compared to EWMA and CUSUM charts for small shifts.
\end{abstract}

Keywords: Grafik Pengendali, Exponentially WeightedMoving Average, Cumulative Sum, Mixed EWMACUSUM, Average Run Lenght, EWMA, CUSUM, MEC, ARL

\section{PENDAHULUAN}

Setiap perusahaan selalu berlomba-lomba untuk menjadi pemenang di dalam persaingan, dengan memberikan produk dan pelayanan terbaik kepada konsumen. Salah satu faktor yang mempengaruhi secara langsung adalah penilaian konsumen terhadap kualitas. Montgomery (2013) mengemukakan bahwa, dalam rangka menjaga kualitas pada proses produksi, akan selalu terdapat variabilitas terhadap hasil produksi. Variabilitas bisa berupa kesalahan-kesalahan kecil maupun kesalahan yang fatal pada proses produksi.

Kualitas produk yang sangat sering dikritisi oleh konsumen adalah produk makanan. Proses produksi makanan yang menggunakan proses manual memiliki kemungkinan yang tinggi untuk terjadinya perbedaan antara pencetakan produk yang satu dengan yang lainnya baik dari segi ukuran, maupun berat produk. Perbedaan atau pergeseran variabel tersebut dapat diamati melalui alat statistik yaitu grafik pengendali. Grafik Pengendali merupakan salah satu alat yang sering digunakan dalam pengendalian kualitas. Grafik pengendali yang pertama kali dikenal adalah grafik pengendali Shewhart. Montgomery (2013) mengemukakan bahwa grafik pengendali Shewart memiliki kerugian yaitu grafik ini hanya menggunakan informasi tentang proses yang terdapat pada observasi sampel terakhir dan mengabaikan informasi yang diberikan oleh seluruh urutan sampel. Berdasarkan kekurangan tersebut, maka dikembangkan grafik pengendali Cumulative Sum (CUSUM) dan Exponentially Weighted Moving Average (EWMA) (Montgomery DC, 2013).

Grafik pengendali CUSUM digunakan sebagai alternatif terhadap grafik pengendali Shewart untuk memonitor rata-rata proses. Diagram ini menghitung langsung semua kumulatif deviasi nilai sampel dari nilai target. Sedangkan grafik pengendali EWMA sangat efektif dalam menyelidiki pergeseran rata-rata yang kecil. Pada tahun 2012, Abbas, N., et al. merekomendasikan Mixed EWMA-CUSUM (MEC) untuk meningkatkan sensitifitas dari struktur grafik pengendali terutama pergeseran mean proses yang kecil. Abbas, et al. (2012) mengemukakan kinerja grafik pengendali Mixed EWMA - CUSUM tidak hanya mengandalkan pengamatan saat ini, tetapi juga mengumpulkan informasi dari pengamatan sebelumnya sehingga memberikan sinyal yang cepat untuk mendeteksi keadaan out of control. 


\section{TINJAUANPUSTAKA}

Wingko merupakan makanan tradisional yang terbuat dari parutan kelapa dan tepung ketan. Wingko dibentuk dengan bentuk bulatan pipih, dibalut dengan kertas minyak dan dimasukkan dalam pembungkus kertas. Wingko merupakan makanan khas dari Babat Kabupaten Lamongan. Nama Babat sendiri diambil dari kecamatan Babat, tempat pertama kali wingko dibuat. Sejarah telah mencatat bahwa wingko babat pertama kali muncul di Semarang sekitar tahun 1946. Wingko babat ini pertama kali dibawa oleh seorang wanita bernama Loe Lan Hwa bersama suaminya, The Ek Tjong (D Mulyono).

\subsection{Pe ngendalian Kualitas}

Kata "kualitas" telah didefinisikan secara beragam oleh beberapa orang ahli dan pakar. Garvin (1984) membagi definisi kualitas menjadi lima kategori, yakni: keutamaan, kualitas berdasar produk, kualitas berdasar pengguna, kualitas berdasar proses manufaktur, dan kualitas berdasarkan nilainya. Pengertian umum tentang kualitas yang sering dipakai adalah dari Crosby (1979). Ia mendefinisikan kualitas sebagai conformance to requirements or specifications (kualitas adalah kesesuaian dengan spesifikasi dan yang dibutuhkan). Pengendalian Kualitas Statistik merupakan cara atau teknik untuk mengendalikan atau mengontrol produksi dengan tujuan agar produk yang dihasilkan stabil dan ideal (berkualitas) sehingga menambah jumlah permintaan konsumen. Montgomery (2013) yang mendefinisikan bahwa pengendalian kualitas aktivitas dan manajemen, yang dengan aktivitas itu dapat diukur ciri-ciri kualitas produk, lalu dibandingkan dengan spesifikasi atau persyaratan dan mengambil tindakan penyehatan yang sesuai apabila ada perbedaan antara penampilan yang sebenarnya dengan yang standar.

\subsection{UjiAsumsi}

Uji asumsi yang harus dipenuhi sebelum melakukan analisis terhadap grafik pengendali adalah asumsi normalitas dan keacakan data pada data yang akan digunakan dalam penelitian. Asumsi normalitas yaitu asumsi bahwa data sampel berasal dari populasi yang berdistribusi normal, dan asumsi keacakan data yaitu data sampel diambil secara acak dan setiap sampel dalam populasi mempunyai peluang yang sama untuk terambil.

1. Uji Normalitas (Kolmogorove-Smirnov)

Daniel (1978) merumuskan hipotesis untuk uji normalitas sebagai berikut :

$\mathrm{H}_{0}$ : Data berdistribusi normal

$\mathrm{H}_{1}$ : Data tidak berdistribusi normal

Taraf Signifikans i : $\alpha$

Statistik uji : $\mathrm{D}=\sup \left|S(\mathrm{x})-F_{0}(\mathrm{x})\right|$

dengan : $S(\mathrm{x})=$ fungsi peluang kumulatif yang dihitung dari sampel

$F_{0}(\mathrm{x})=$ fungsi peluang kumulatif yang dihipotesiskan

nilai $S(\mathrm{x})$ dan $F_{0}(\mathrm{x})$ diperoleh dari perhitungan berikut :

$S(\mathrm{x})=$ proporsi nilai-nilai pengamatan dalam sampel yang kurang atatu sama dengan $\mathrm{x}$

$=\frac{\text { (banyaknya nilai pengamatan dalam sampel yang kurang dari atau sama dengan } \mathrm{x} \text { ) }}{\mathrm{n}}$

dengan : $\mathrm{n}=$ banyaknya data

Daniel (1978) dalam bukunya menyatakan $F_{0}(\mathrm{x})=P(0 \leq Z \leq \mathrm{z})$, dengan $F_{0}(\mathrm{x})$ adalah fungsi distribusi suatu populasi berdistribusi normal : 


$$
\mathrm{z}=(\mathrm{x}-\mu) / \sigma
$$

Untuk mendapatkan nilai $F_{0}(\mathrm{x})$, maka nilai $x$ yang teramati diganti dengan nilai variabel $z$ normal standar (Daniel 1978). Kemudian untuk mencari luas daerah antara 0 dan $z$ ( $P(0 \leq$ $Z \leq \mathrm{z})$ ) didapat dengan menggunakan bantuan perangkat lunak $\mathrm{R}$.

Kriteria $\mathrm{Uji}: \mathrm{H}_{0}$ ditolak jika nilai $\mathrm{D}>\mathrm{D}_{\alpha ; \mathrm{n}}$ atau $\mathrm{p}$-value $<\alpha$

\section{Uji Keacakan Data (Run Test)}

Sujarweni dan Endrayanto (2012) dalam bukunya menyatakan uji hipotesis untuk kerandoman data (Uji Run Test) adalah sebagai berikut :

Hipotesis :

$\mathrm{H}_{0}$ : urutan data merupakan urutan random / acak

$\mathrm{H}_{1}$ : urutan data bukan merupakan urutan random / acak

Taraf Signifikansi : $\alpha$

Statistik Uji : $Z_{\text {hitung }}=\frac{r-\mu_{r}}{\sigma_{r}}$

Nilai $\mu_{r}$ dan $\sigma_{r}$ diperoleh dari perhitungan berikut :

dengan : $\mathrm{n}_{1}=$ jumlah data bertanda $(+)$

$$
\mu_{r}=\frac{2 n_{1} n_{2}}{n_{1}+n_{2}}+1 \sigma_{r}=\sqrt{\frac{2 n_{1} n_{2}\left(2 n_{1} n_{2}-n_{1}-n_{2}\right)}{\left(n_{1}+n_{2}\right)^{2}\left(\left(n_{1}+n_{2}-1\right)\right.}}
$$

$\mathrm{n}_{2}=$ jumlah data bertanda (-)

$\mathrm{r}=$ jumlah run pada sampel

Kriteria Uji : $\mathrm{H}_{0}$ ditolak jika nilai $Z_{\text {hitung }}<-Z_{\alpha / 2}$ atau $Z_{\text {hitung }}>Z_{\alpha / 2}$

\subsection{Grafik Pengendali EWMA, CUSUM, dan MEC}

\section{EWMA}

Grafik pengendali Exponentially Weighted Moving Average (EWMA) berfungsi untuk mengontrol pergeseran mean proses dari target. Kinerja grafik EWMA ditentukan oleh parameter batas kendali $L$ dan smoothing parameter $\lambda$. Kedua parameter $(L, \lambda)$.

$$
Z_{i}=\lambda x_{i}+(1-\lambda) Z_{i-1}
$$

dengan $Z_{0}=\mu_{0}$, seringkali rata-rata data awal digunakan sebagai nilai awal EWMA $(\bar{x}=$ $\mu_{0}$ ), maka $Z_{0}=\bar{x}, Z_{i}$ merupakan statistik EWMA pada waktu ke- $i, \lambda$ adalah nilai konstanta, $0 \leq \lambda \leq 1$ dan $x_{i}$ adalah nilai pengamatan ke-i, $i=1,2,3, \ldots, N$. Montgomery (2013) mengemukakan bahwa nilai $\lambda$ terbaik adalah $0,05 \leq \lambda \leq 0,25$. Garis tengah untuk grafik EWMA CL $=\mu_{0}$ dengan batas pengendali

$$
\begin{aligned}
& \left.\mathrm{UCL}=\mu_{0}+\operatorname{L\sigma } \sqrt{\frac{\lambda}{2-\lambda}\left[1-(1-\lambda)^{2 i}\right.}\right] \\
& \left.\mathrm{LCL}=\mu_{0}-\mathrm{L} \sigma \sqrt{\frac{\lambda}{2-\lambda}\left[1-(1-\lambda)^{2 i}\right.}\right]
\end{aligned}
$$

\section{CUSUM}

Grafik pengendali CUSUM berfungsi untuk mendeteksi pergeseran mean proses dari target. Ada dua cara untuk mempresentasikan CUSUM, yaitu tabular CUSUM dan V-mask CUSUM. Grafik tabular CUSUM dapat digunakan untuk data individu (tunggal) maupun data subgrup. Kinerja grafik pengendali CUSUM apabila terjadi pergeseran proses ratarata target yang telah ditentukan ia akan memberikan sinyal dan pendeteksian. Nilai tabular cusum (dinotasikan dengan $\mathrm{Ci}+$ dan $\mathrm{Ci}$-) disebut sebagai penggambaran data satu sisi keatas (+) dan satu sisi kebawah (-) untuk memonitor rata-rata proses (Koshti 2011). Berikut persamaan untuk Tabular Cusum : 


$$
\begin{aligned}
& \mathrm{C}_{\mathrm{i}}^{+}=\max \left[0 ; \overline{x_{i}}\left(\mu_{0}+K\right)+\mathrm{C}_{\mathrm{i}-1}{ }^{+}\right] \\
& \mathrm{C}_{\mathrm{i}}^{-}=\max \left[0 ;\left(\mu_{0}-K\right)-\overline{x_{i}}+\mathrm{C}_{\mathrm{i}-1^{-}}\right]
\end{aligned}
$$

dengan $\mathrm{C}_{0}{ }^{+}=\mathrm{C}_{0^{-}}=0$, Nilai $\mathrm{K}$ biasa disebut dengan nilai referensi $K=\frac{\delta}{2} \sigma_{\bar{x}}=\frac{|\mu 1-\mu 0|}{2}$ dan $\delta$ $=\frac{|\mu 1-\mu 0|}{\sigma_{\bar{x}}}, \mathrm{x}_{\mathrm{i}}$ merupakan sampel ke-i, $\mathrm{i}=1,2,3, \ldots, \mathrm{m}$ untuk data subgrup $\mathrm{x}_{\mathrm{i}}$ digantikan dengan $\overline{x_{i}}=\sum_{j=1}^{n} \frac{x_{i j}}{n}$ yaitu rata-rata sampel ke-i. Tabular CUSUM dirancang dengan menghitung nilai referensi $\mathrm{K}$ dan interval keputusan $\mathrm{H}$. Tabular Cusum dapat dikatakan out of control jika nilai $\mathrm{Ci}+$ dan $\mathrm{Ci}$ - keluar dari interval $\mathrm{H}$ atau yang biasa disebut batas kontrol, yaitu $\mathrm{Ci}_{+}$ $>\mathrm{H}$ atau $\mathrm{Ci}->\mathrm{H}$.

$$
\mathrm{H}=\mathrm{h} \sigma_{\bar{x}}
$$

Pada bukunya, Montgomery (2013) menerangkan bahwa parameter tersebut dipilih untuk memberikan kinerja yang baik pada Average Run Lenght (ARL), sehingga ditetapkan :

$$
\mathrm{K}=\mathrm{k} \sigma
$$

dengan $\sigma$ adalah standar deviasi sampel, $h$ dan $k$ merupakan konstanta. Nilai yang direkomendasikan adalah $\mathrm{h}=4$ dan $\mathrm{h}=5$ dan nilai $k=0,5$ umumnya akan memberikan kinerja yang baik terhadap ARL pada pergeseran $1 \sigma$ dalam rata-rata proses (Montgomery DC, 2013).

\section{MEC}

Abbas, et al. (2012) merekomendasikan grafik pengendali Mixed EWMA-CUSUM yang merupakan grafik yang menggabungkan grafik pengedali EWMA dan garfik pengendali CUSUM untuk mendeteksi pergeseran rata-rata yang kecil. Metode ini didefinisikan pada persamaan sebagai berikut :

$$
\begin{aligned}
& \operatorname{MEC}_{\mathrm{i}}^{+}=\max \left[0 ;\left(\mathrm{Q}_{\mathrm{i}-} \mu_{0}\right)-a_{i}+\mathrm{MEC}_{\mathrm{i}-1}{ }^{+}\right] \\
& \mathrm{MEC}_{\mathrm{i}}^{-}=\max \left[0 ;-\left(\mathrm{Q}_{\mathrm{i}}-\mu_{0}\right)-a_{i}+\mathrm{MEC}_{\mathrm{i}-1^{-}}\right]
\end{aligned}
$$

Grafik pengendali ini menggambarkan data dengan dua sisi seperti grafik CUSUM dengan $\mathrm{MEC}_{i}^{+}$merupakan penggambaran data sisi atas dan $\mathrm{MEC}_{i}^{-}$penggambaran data sisi bawah dengan $\mathrm{MEC}_{0}^{+}=\mathrm{MEC}_{0}^{-}=0$. Parameter $a_{i}$ merupakan nilai referensi variabel dari waktu ke waktu akibat varian dari statistik EWMA $Q_{i}$, yang didesinisikan sebagai berikut :

$$
\begin{gathered}
a_{i}=a^{*} \sqrt{\operatorname{Var}\left(Q_{i}\right)}=a^{*} \sigma_{\bar{x}} \sqrt{\frac{\lambda_{q}}{2-\lambda_{q}}\left[1-\left(1-\lambda_{q}\right)^{2 i}\right]} \\
Q_{i}=\lambda_{q} \bar{x}_{i}+\left(1-\lambda_{q}\right) Q_{i-1}
\end{gathered}
$$

dengan $\mathrm{a}^{*}$ merupakan nilai konstanta seperti parameter $\mathrm{k}$ pada grafik CUSUM dan $\lambda_{q}$ merupakan pembobot $\lambda$ terpilih dari grafik EWMA $0<\lambda_{q}<1$. Statistik $M E C_{i}^{+}$dan $M E C_{i}^{-}$ diplotkan terhadap batas kontrol.

$$
b_{i}=b^{*} \sigma_{\bar{x}} \sqrt{\frac{\lambda_{q}}{2-\lambda_{q}}\left[1-\left(1-\lambda_{q}\right)^{2 i}\right]}
$$

\subsection{Average Run Length}

Kriteria yang digunakan untuk dapat membandingkan kinerja grafik pengendali adalah dengan mengukur kecepatan grafik pengendali tersebut dalam mendeteksi sinyal out of control. Grafik pengendali yang lebih cepat mendeteksi sinyal out of control disebut lebih sensitif terhadap perubahan proses. Salah satu cara untuk mengukur kinerja grafik pengendali adalah dengan menggunakan Average Run Length (ARL). Average Run Length (ARL) adalah banyak titik sampel rata-rata yang digambarkan sebelum satu titik 
menunjukkan keadaan tidak terkendali. Untuk sembarang grafik pengendali Shewart, ARL dirumuskan :

$$
\mathrm{ARL}=\frac{1}{\alpha}
$$

dengan $\alpha$ adalah probabilitas bahwa suatu tiitk melebihi batas pengendali.

1. Average Run Length (ARL) untuk CUSUM

$\mathrm{ARL}_{0}$ merupakan nilai atau banyaknya titik sampel pada saat proses in control sedangkan $\mathrm{ARL}_{1}$ merupakan nilai atau titik sampel pada saat proses out of control. Montgomery (2013) mengemukakan untuk one-side CUSUM dengan parameter $h$ dan $k$, maka perhitungan ARL menjadi :

$$
\mathrm{ARL}=\frac{\exp (-2 \Delta m)+2 \Delta m-1}{2 \Delta^{2}}
$$

Untuk $\Delta \neq 0$, dengan :

$\Delta=\delta-k$ untuk CUSUM sisi atas $\left(\mathrm{Ci}^{+}\right), \mathrm{ARL}^{+}=\frac{\exp (-2(\delta-k) m)+2(\delta-k) m-1}{2(\delta-k)^{2}}$

$\Delta=-\delta-k$ untuk CUSUM sisi bawah $\left(\mathrm{Ci}^{-}\right), \mathrm{ARL}^{-}=\frac{\exp (-2(-\delta-k) m)+2(-\delta-k) m-1}{2(-\delta-k)^{2}}$

$\mathrm{m}=\mathrm{h}+1,166$ dan $\delta=\frac{\left(\mu_{1}+\mu_{0}\right)}{\sigma}$

jika $\Delta=0, \mathrm{ARL}=\mathrm{m}^{2}$

Nilai $\delta$ mewakili pergeseran rata-rata dalam $1 \sigma$ sehingga ARLnya dapat dihitung. Oleh karena itu, jika $\delta=0$, ARL dapat dihitung dengan rumus (19) sedangkan jika $\delta \neq 0$, perhitungan nilai ARL sesuai dengan pergeseran dari nilai $\delta$. Untuk mendapatkan nilai ARL dari dua sisi CUSUM yang disebut $\mathrm{ARL}^{+}$dan $\mathrm{ARL}-$ digunakan rumus :

$$
\frac{1}{A R L}=\frac{1}{A R L^{+}}+\frac{1}{A R L^{-}}
$$

\section{METODOLOGI PENELITIAN}

\subsection{Jenis dan Sumber Data}

Data yang digunakan dalam penelitian ini adalah data primer yang diperoleh dari pabrik Wingko Babat Cap "Moel". Data inspeksi produksi pabrik Wingko Babat Cap "Moel" yang digunakan yaitu data variabel berat bersih wingko babat pada bulan November - Desember 2019 yang terdapat 30 sampel wingko babat dengan 5 kali pengulangan sehingga total data sebanyak 150.

\subsection{Variabel Penelitian}

Variabel yang digunakan dalam penelitian ini adalah variabel $\mathrm{X}$ yaitu data berat bersih wingko babat yang terdiri dari 30 sampel dengan 5 kali pengulangan $\left(\mathrm{X}_{1}, \mathrm{X}_{2}, \mathrm{X}_{3}, \mathrm{X}_{4}\right.$, dan $\left.\mathrm{X}_{5}\right)$.

\subsection{Langkah Metode Analis is}

1. Pengumpulan data

2. Melakukan uji asumsi yang harus terpenuhi yaitu normalitas (Kolmogorov Smirnov) dan keacakan data (Run Test)

3. Pengendalian proses produksi dengan membentuk grafik pengendali EWMA

a. Memasukkan data

b. Menentukan parameter $(\lambda, L)$ 
c. Menghitung batas kendali UCL dan LCL dengan parameter $(\lambda, L)$

d. Menghitung nilai $Z_{i}$ pada persamaan (1)

e. Membentuk grafik pengendali EWMA dengan parameter $\lambda$, jika grafik terkendali maka proses dilanjutkan. Jika tidak, maka dilakukan perbaikan pada peta kendali.

4. Pengendalian proses produksi dengan membentuk grafik pengendali CUSUM

a. Memasukkan data

b. Menentukan nilai standar deviasi sampel $\left(\sigma_{\bar{x}}\right)$

c. Menghitung batas kendali UCL dan LCL dengan parameter $h$

d. Menghitung nilai Tabular CUSUM $\left(\mathrm{C}_{\mathrm{i}}^{+}\right.$dan $\left.\mathrm{C}_{\mathrm{i}}^{-}\right)$pada persamaan (4) dan (5)

e. Membentuk grafik pengendali CUSUM, jika grafik jika grafik terkendali maka proses dilanjutkan. Jika tidak, dilakukan perbaikan pada peta kendali.

5. Pengendalian proses produksi dengan membentuk grafik pengendali MEC

a. Memasukkan data

b. Menentukan parameter $\left(\lambda_{q}, b^{*}\right)$

c. Menghitung batas kendali UCL dan LCL dengan parameter $\left(\lambda_{q}, b^{*}\right)$

d. Menghitung nilai $M E C_{i}^{+}$dan $M E C_{i}^{-}$pada persamaan (8) dan (9)

e. Membentuk grafik pengendali MEC, jika grafik terkendali maka proses dilanjutkan.

Jika tidak, maka dilakukan perbaikan pada peta kendali.

6. Menghitung nilai ARL untuk grafik EWMA, CUSUM, dan MEC dan melakukan pemeriksaan kesensitifan grafik dengan me;ihat nilai ARL terkecil dariketiga grafik.

\section{HASIL DAN PEMBAHASAN}

\subsection{Uji Aumsi}

1. Uji Asumsi Normalitas (Kolmogorov-Smirnov)

Uji asumsi normalitas Kolmogorov-Smirnov pada data berat bersih wingko babat cap "Moel" menggunakkan taraf signifikansi 5\%, dengan $\mathrm{H}_{0}$ merupakan data berdistribusi normal dan $\mathrm{H}_{1}$ merupakan data tidak berdistribusi normal (Daniel, 1978). Hipotesis nol $\left(H_{0}\right)$ ditolak jika nilai p-value kurang dari taraf signifikansi $(\alpha=5 \%)$. Nilai $p$-value yang didapat untuk data rata-rata sampel $\left(\bar{x}_{\mathrm{i}}\right)$ adalah 0,05421 memiliki nilai yang lebih besar daripada taraf signifikansi 0,05 sehingga dapat disimpulkan bahwa data rata-rata sampel berat bersih wingko babat berdistribusi normal.

2. Uji Asumsi Keradoman Data (Run Test)

Uji asumsi kerandoman data merupakan uji asumsi kedua yang harus dipenuhi untuk melakukan analisis grafik pengendali EWMA, CUSUM, dan MEC. Menggunakan taraf signifikansi $5 \%$, dengan $\mathrm{H}_{0}$ merupakan urutan data random/acak dan $\mathrm{H}_{1}$ merupakan urutan data bukan random/acak (Sujarweni dan Endrayanto, 2012). Nilai $p$-value untuk data ratarata sampel $\left(\bar{x}_{i}\right)$ sebesar 0,13720 lebih besar daripada nilai $\alpha / 2(0,025)$ maka $\mathrm{H}_{0}$ diterima sehingga disimpulkan bahwa data rata-rata berat bersih wingko babat merupakan data random/acak.

\subsection{Grafik Pengendali EWMA}

Kinerja grafik EWMA pada studi kasus dengan parameter $\lambda=0,1 L=2,824$ dapat dilihat pada Gambar 1. Semua plot data berada di dalam batas pengendali. Hal ini menunjukkan bahwa proses dalam keadaan terkendali. Garis tengah atau CL (Central Limit) menunjukkan nilai $\mu_{0}=\overline{\bar{x}}$ sebesar 17,526 Nilai-nilai Batas Pengendali Atas dan Batas Pengendali Bawah berubah-ubah secara tidak signifikan pada sampel berikutnya. Berikut perhitungan batas kendali untuk sampel pertama dengan menggunakan persamaan (2) dan (3). 
Batas Pengendali Atas : $\left.\mathrm{UCL}_{1}=17,526+2,824 \times 0,5151593 \sqrt{\frac{0,1}{2-0,1}\left[1-(1-0,1)^{2 \times 1}\right.}\right]$ $=17,67148$

Batas Pengendali Bawah : $\mathrm{LCL}_{1}=17,526-2,824 \times 0,5151593 \sqrt{\frac{0,1}{2-0,1}\left[1-(1-0,1)^{2 \times 1}\right]}$ $=17,38052$

Nilai $Z_{i}$ akan dihitung menggunakan nilai rata-rata sampel pertama. Berikut perhitungan untuk $Z i$ (1) dengan $Z_{0}=\overline{\bar{x}}=\frac{\sum_{i=1}^{30} \bar{x} i}{30}=17,526$

Statistik EWMA : $Z_{1}=0,25 \times 18,894+(1-0,1) * 17,526=17,66280$

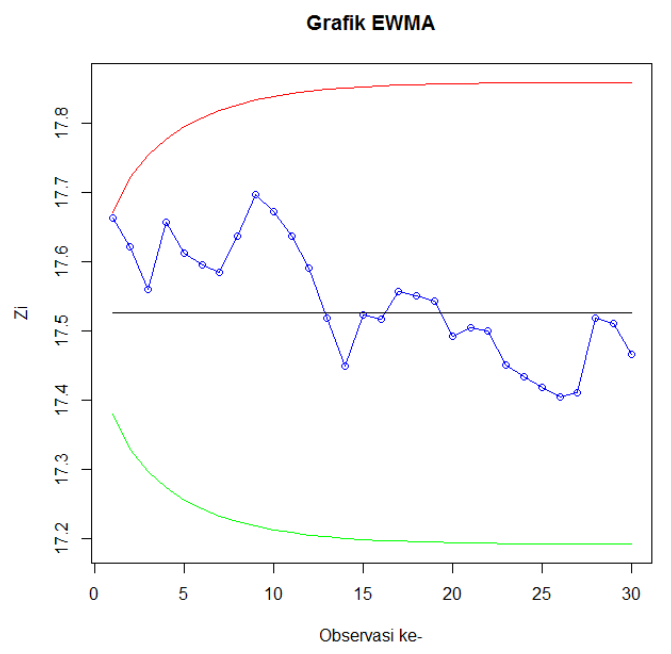

Gambar 1. Grafik Pengendali EWMA

\subsection{Grafik Pengendali CUSUM}

Parameter untuk menggambarkan grafik tabular CUSUM diantaranya rata-rata populasi $\left(\mu_{0}\right)$, nilai parameter $h$ dan $k$. Nilai rata-rata populasi $\left(\mu_{0}\right)$ dari data berat bersih wingko babat didapat sebesar 17,526 dengan parameter $h$ dan $k$ berturut-turut adalah sebesar 5 dan 0,5. Nilai parameter $h$ dan $k$ yang digunakan pada studi kasus ini diambil berdasarkan hasil simulasi yang dibuat oleh Zaman et al. (2014). Grafik Pengendali Tabular CUSUM menggambarkan data dalam dua sisi. Garis berwarna biru pada Gambar 2. menunjukkan plot data sisi atas $\left(\mathrm{C}_{\mathrm{i}}^{+}\right)$dan garis berwarna merah menunjukkan plot data sisi bawah $\left(\mathrm{C}_{\mathrm{i}}^{-}\right)$. Pada gambar terlihat bahwa plot-plot data berada di dalam batas pengendali ini menunjukkan bahwa semua proses dalam keadaan terkendali. Untuk menentukan nilai tabular CUSUM dan batas pengendali, diperlukan perhitungan untuk reference value $(K)$ dan standar deviasi sampel.

$\sigma_{\bar{x}}=\sqrt{\frac{\sum\left(\bar{x}_{i}-\overline{\bar{x}}\right)^{2}}{N-1}}=0,51516$.

$\mathrm{K}=\mathrm{k} \times \sigma_{\bar{x}}=0,5 \times 0,51516=0,25758$

Berikut nilai tabular CUSUM untuk data sampel pertama menggunakan persamaan (4) dan (5) :

$$
\begin{aligned}
\mathrm{C}_{1}{ }^{+} & =\max [0 ; 18,89400-(17,52600+0,25758)+0] \\
& =\max [0 ; 1,11042] \\
& =1,11042 \\
\mathrm{C}_{1}{ }^{-} & =\max [0 ;(17,52600-0,25758)-18,89400+0] \\
& =\max [0 ;-1,62600]
\end{aligned}
$$


$=0$

Perhitungan batas kendali untuk data sampel pertama menggunakan parameter $h=5$ dan $\sigma_{\bar{x}}=0,51516:$

$\mathrm{H}=\mathrm{h} \sigma_{\bar{x}}$

$=5 \times 0,51516$

$=2,57579$

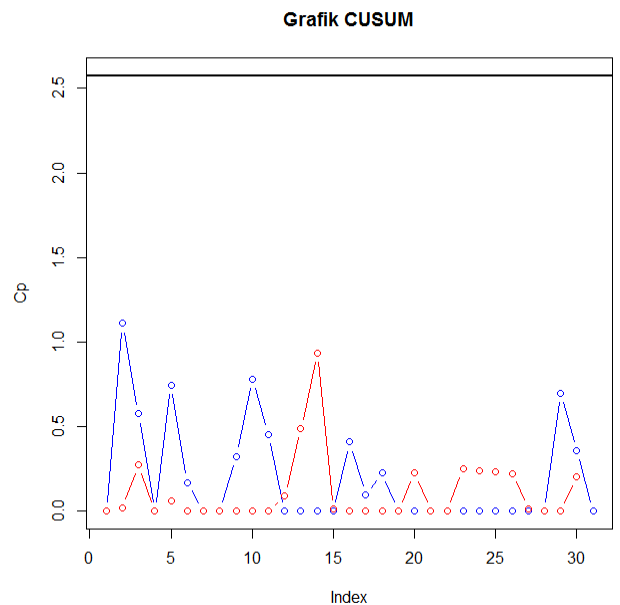

Gambar 2. Grafik Pengendali Tabular CUSUM

\subsection{Grafik Pengendali MEC}

Data pada grafik MEC digambarkan dengan dua sisi seperti grafik tabular CUSUM, sisi atas dilambangkan dengan $\mathrm{MEC}_{\mathrm{i}}{ }^{+}$dan sisi bawah dilambangkan dengan $\mathrm{MEC}_{\mathrm{i}}^{-}$. Parameter yang dibutuhkan dalam analisis batas kendali grafik MEC yaitu $a^{*}=0,5 ; b^{*}=$ 37,$42 ; \lambda_{q}=0,1$. Pemilihan niai parameter $\lambda_{q}=0,1$ dan $b^{*}=37,42$ disesuaikan dari pemilihan parameter yang menghasilkan nilai ARL terkecil untuk grafik MEC. Sedangkan parameter $a^{*}=0,5$ disesuaikan dari grafik CUSUM yang menggunakan $k=0,5$. Berikut menghitung nilai $\mathrm{MEC}_{\mathrm{i}}{ }^{+}$dan $\mathrm{MEC}_{\mathrm{i}}^{-}$untuk data sampel pertama.

$a_{i}=a^{*} \sqrt{\operatorname{Var}\left(Q_{i}\right)}=a^{*} \sigma_{\bar{x}} \sqrt{\frac{\lambda_{q}}{2-\lambda_{q}}\left[1-\left(1-\lambda_{q}\right)^{2 i}\right]}$

$a_{1}=0,5 \times 0,51516 \sqrt{\frac{0,1}{2-0,1}\left[1-(1-0,1)^{2 * 1}\right]}$

$=0,025758$ dan seterusnya hingga sampel ke-30

$Q_{i}=\lambda_{q} \bar{x}_{i}+\left(1-\lambda_{q}\right) Q_{i-1}$

$Q_{1}=0,25 \times 18,89400+(1-0,1) \times 17,526=20,29690$

Statistik MEC untuk data sampel ke-1 menggunakan persamaan (8) dan (9) dengan $\mathrm{MEC}_{0}{ }^{+}$ $=0, \mathrm{MEC}_{0^{-}}=0$ :

$$
\begin{aligned}
\mathrm{MEC}_{1}{ }^{+}=\max & {[0 ;(20,29690-17,526)-0,025758+0] } \\
& =\max [0 ; 0,111042037] \\
& =0,111042037 \\
\mathrm{MEC}_{\mathrm{i}}^{-}=\max [ & {\left[0 ;-\left(\mathrm{Q}_{\mathrm{i}}-\mu_{0}\right)-a_{i}+\mathrm{MEC}_{\left.\mathrm{i}-1^{-}\right]}\right.} \\
\mathrm{MEC}_{1}{ }^{-}=\max & {[0 ;-(20,29690-17,526)-0,025758+0] } \\
& =\max [0 ;-2,796658] \\
& =0
\end{aligned}
$$

Perhitungan batas kendali untuk sampel pertama menggunakan persamaan (11) : 


$$
b_{1}=37,42 \times 0,51516 \sqrt{\frac{0,1}{2-0,1}\left[1-(1-0,1)^{2 \times 1}\right]}=1,927726
$$

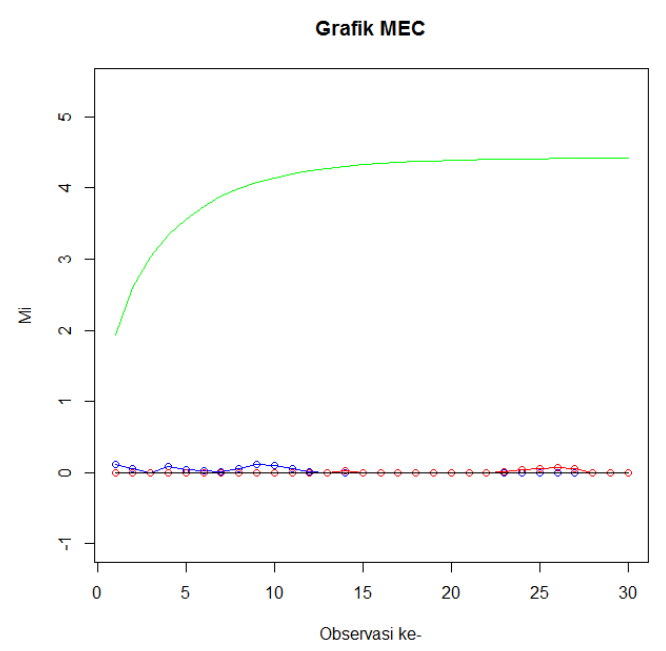

Gambar 3. Grafik Pengendali MEC

Pada Gambar 3 batas pengendali grafik Mixed Exponentially Weighted Moving Average-Cumulative Sum (MEC) ditunjukkan oleh garis berwarna hijau pada sisi atas grafik. Gambar 3 menunjukkan titik-titik plot data yang digambarkan melalui dua sisi, sisi atas berwarna biru $\left(\mathrm{MEC}_{\mathrm{i}}^{+}\right)$dan sisi bawah berwarna merah $\left(\mathrm{MEC}_{\mathrm{i}}^{-}\right)$berada didalam batas pengendali. Berdasarkan output program R pada grafik MEC menunjukkan bahwa seluruh data sampel terkendali.

\subsection{Average Run Length (ARL)}

Nilai Average Run Length untuk grafik EWMA, CUSUM, dan MEC untuk $0 \leq \delta \leq 2$ dapat dilihat pada Tabel 1,Tabel 2, Tabel 3, dan Tabel 4. Nilai ARL untuk EWMA yang didapatkan menggunakan parameter $\lambda=0,1$ dan $\mathrm{L}=2,824, \lambda=0,25$ dan $\mathrm{L}=3, \lambda=0,5$ dan $\mathrm{L}=3,072, \lambda=0,75$ dan $\mathrm{L}=3,088$, prameter tersebut dipilih berdasarkan rekomendasi Abbas, et al. (2012), untuk grafik CUSUM menggunakan parameter $\mathrm{k}=0,5 \mathrm{dan} \mathrm{h}=5$ berdasarkan rekomendasi Montgomery (2013), dan untuk grafik MEC menggunkaan parameter $\lambda_{\mathrm{q}}=0,1$ dan $\mathrm{b}^{*}=37,42 ; \lambda_{\mathrm{q}}=0,25$ dan $\mathrm{b}^{*}=20,18 ; \lambda_{\mathrm{q}}=0,5$ dan $\mathrm{b}^{*}=11,2 ; \lambda \mathrm{q}=$ 0,75 dan $^{*}=7,32$ berdasarkan rekomendasi Abbas, et al. (2012).

Tabel 1. Perbandingan ARL CUSUM $(k=0,5, h=5)$, EWMA $(\lambda=0,1, L=2,824)$, dan $\operatorname{MEC}\left(\lambda_{q}=0,1, b^{*}=37,42\right)$

\begin{tabular}{|c|c|c|c|}
\hline \multirow[t]{2}{*}{$\boldsymbol{\delta}$} & CUSUM & EWMA & MEC \\
\hline & $\mathrm{k}=0,5 \quad \mathrm{~h}=5$ & $\lambda=0,1 \quad \mathrm{~L}=2,824$ & $\lambda q=0,1 \quad b^{*}=37,42$ \\
\hline $\mathbf{0}$ & 930,88700 & 624,97660 & 498,38820 \\
\hline 0,25 & 141,68770 & 95,87775 & 80,13585 \\
\hline 0,5 & 380,09610 & 30,37126 & 35,52400 \\
\hline $\mathbf{0 , 7 5}$ & 17,04853 & 15,63513 & 24,05220 \\
\hline 1 & 10,37598 & 10,26789 & 18,86370 \\
\hline 1,5 & 5,74722 & 6,08830 & 13,79075 \\
\hline 2 & 4,00887 & 4,37434 & 11,19775 \\
\hline
\end{tabular}


Tabel 2. Perbandingan ARL CUSUM $(k=0,5, h=5)$, EWMA $(\lambda=0,25, L=3)$, dan $\operatorname{MEC}\left(\lambda_{q}=0,25, b^{*}=20,18\right)$

\begin{tabular}{|c|c|c|c|c|c|}
\hline \multirow{2}{*}{$\delta$} & \multicolumn{2}{|c|}{ CUSUM } & \multicolumn{2}{|c|}{ EWMA } & MEC \\
\hline & $\mathrm{k}=0,5$ & $h=5$ & $\lambda=0,25$ & $\mathrm{~L}=3$ & $\lambda q=0,25 \quad b^{*}=20,18$ \\
\hline 0 & \multicolumn{2}{|c|}{930,88700} & \multicolumn{2}{|c|}{675,68180} & 502,01800 \\
\hline 0,25 & \multicolumn{2}{|c|}{141,68770} & \multicolumn{2}{|c|}{149,50630} & 83,75290 \\
\hline 0,5 & \multicolumn{2}{|c|}{380,09610} & \multicolumn{2}{|c|}{45,94317} & 30,88825 \\
\hline 0,75 & \multicolumn{2}{|c|}{17,04853} & \multicolumn{2}{|c|}{19,73528} & 18,87550 \\
\hline 1 & \multicolumn{2}{|c|}{10,37598} & \multicolumn{2}{|c|}{10,03355} & 13,88160 \\
\hline 1,5 & \multicolumn{2}{|c|}{5,74722} & \multicolumn{2}{|c|}{5,45029} & 9,60360 \\
\hline 2 & \multicolumn{2}{|c|}{4,00887} & \multicolumn{2}{|c|}{3,61304} & 7,59055 \\
\hline
\end{tabular}

Tabel 3. Perbandingan ARL CUSUM $(k=0,5, h=5)$, EWMA $(\lambda=0,5, \mathrm{~L}=3,072)$, dan $\operatorname{MEC}\left(\lambda_{q}=0,5, b^{*}=11,2\right)$

\begin{tabular}{|c|c|c|c|c|c|c|}
\hline \multirow{2}{*}{$\delta$} & \multicolumn{2}{|c|}{ CUSUM } & \multicolumn{2}{|c|}{ EWMA } & \multicolumn{2}{|c|}{ MEC } \\
\hline & $\mathrm{k}=0,5$ & $h=5$ & $\lambda=0,5$ & $\mathrm{~L}=3,072$ & $\lambda q=0,5$ & $b^{*}=11,2$ \\
\hline 0 & \multicolumn{2}{|c|}{930,88700} & \multicolumn{2}{|c|}{752,01220} & \multicolumn{2}{|c|}{507,95550} \\
\hline 0,25 & \multicolumn{2}{|c|}{141,68770} & \multicolumn{2}{|c|}{233,86020} & \multicolumn{2}{|c|}{100,26350} \\
\hline 0,5 & \multicolumn{2}{|c|}{380,09610} & \multicolumn{2}{|c|}{83,42250} & \multicolumn{2}{|c|}{30,74660} \\
\hline 0,75 & \multicolumn{2}{|c|}{17,04853} & \multicolumn{2}{|c|}{34,93421} & \multicolumn{2}{|c|}{16,63990} \\
\hline 1 & \multicolumn{2}{|c|}{10,37598} & \multicolumn{2}{|c|}{17,27732} & \multicolumn{2}{|c|}{11,45835} \\
\hline 1,5 & \multicolumn{2}{|c|}{5,74722} & \multicolumn{2}{|c|}{6,51189} & \multicolumn{2}{|c|}{7,29565} \\
\hline 2 & \multicolumn{2}{|c|}{4,00887} & \multicolumn{2}{|c|}{3,62703} & \multicolumn{2}{|c|}{5,52345} \\
\hline
\end{tabular}

Tabel 4. Perbandingan ARL CUSUM $(k=0,5, h=5)$, EWMA $(\lambda=0,75, L=3,088)$, dan MEC $\left(\lambda_{q}=0,75, b^{*}=7,32\right)$

\begin{tabular}{|c|c|c|c|c|c|c|}
\hline \multirow{2}{*}{$\delta$} & \multicolumn{2}{|c|}{ CUSUM } & \multicolumn{2}{|c|}{ EWMA } & \multicolumn{2}{|c|}{ MEC } \\
\hline & $\mathrm{k}=0,5$ & $h=5$ & $\lambda=0,75$ & $\mathrm{~L}=3,088$ & $\lambda q=0,75$ & $\mathrm{~b}^{*}=7,32$ \\
\hline 0 & \multicolumn{2}{|c|}{930,88700} & \multicolumn{2}{|c|}{818,87950} & \multicolumn{2}{|c|}{507,51520} \\
\hline 0,25 & \multicolumn{2}{|c|}{141,68770} & \multicolumn{2}{|c|}{318,71720} & \multicolumn{2}{|c|}{121,98830} \\
\hline 0,5 & \multicolumn{2}{|c|}{380,09610} & \multicolumn{2}{|c|}{133,71720} & \multicolumn{2}{|c|}{33,50540} \\
\hline 0,75 & \multicolumn{2}{|c|}{17,04853} & \multicolumn{2}{|c|}{60,60096} & \multicolumn{2}{|c|}{16,61390} \\
\hline 1 & \multicolumn{2}{|c|}{10,37598} & \multicolumn{2}{|c|}{30,14426} & \multicolumn{2}{|c|}{10,61070} \\
\hline 1,5 & \multicolumn{2}{|c|}{5,74722} & \multicolumn{2}{|c|}{9,87482} & \multicolumn{2}{|c|}{6,31010} \\
\hline 2 & \multicolumn{2}{|c|}{4,00887} & \multicolumn{2}{|c|}{4,53926} & \multicolumn{2}{|c|}{4,58900} \\
\hline
\end{tabular}

Dari perbandingan nilai grafik yang telah disajikan pada Tabel 1, Tabel, 2 Tabel 3, dan Tabel 4 diketahui bahwa grafik pengendali MEC lebih sensitif daripada grafik EWMA dan CUSUM dalam mendeteksi titik-titik yang berada dalam keadaan out of control dengan pergeseran yang kecil. Hal ini ditunjukkan dengan nilai ARL grafik pengendali MEC memiliki nilai terkecil dibandingkan dengan grafik pengendlai EWMA dan CUSUM untuk pergeseran $0,25 \leq \delta \leq 1$, dengan parameter $\mathrm{h}=5, \mathrm{k}=0,5 ; 0,1 \leq \lambda \leq 0,75 ; a=0,5,7,32 \leq b^{*}$ $\leq 37,42,0,1 \leq \lambda_{q} \leq 0,75$. Hal ini menyatakan bahwa grafik pengendali MEC membutuhkan lebih sedikit titik-titik plot data yang in control sebelum ditemukan satu titik yang out of control daripada grafik pengendali EWMA dan CUSUM. Grafik pengendali Mixed 
Exponentially Weighted Moving Average-Cumulative Sum efektif dalam mendeteksi pergeseran mean proses yang kecil pada saat parameter $a^{*}=0,5, \mathrm{~b}^{*}=37,42$, dan $\lambda_{q}=0,1$.

\section{KESIMPULAN}

Berdasarkan nilai parameter yang sudah ditentukan untuk ketiga grafik (EWMA, CUSUM, MEC) diperoleh bahwa proses dalam keadaan terkendali untuk ketiga grafik. Hal ini dapat dilihat dari plot-plot data untuk ketiga grafik berada di dalam beta pengendali. Dari tabel ARL diperoleh bahwa grafik pengendali Mixed Exponentially Weighted Moving Average-Cumulative Sum (MEC) memiliki nilai ARL terkecil dibandingkan dengan grafik pengendlai EWMA dan CUSUM pada pergeseran $0,25 \leq \delta \leq 1$ yang berarti grafik MEC efektif dalam mendeteksi pergeseran mean proses yang kecil. Grafik pengendali MEC membutuhkan lebih sedikit titik-titik plot data yang in control sebelum ditemukan satu titik yang out of control daripada grafik pengendali EWMA dan CUSUM.

\section{DAFTAR PUSTAKA}

Abbas, Riaz and Ronald J.M.M. 2012. Mixed Exponentially Weighted Moving AverageCumulative Sum Charts for Proces Monitoring. Quality and Reliability Enginering International

Crosby, P.B. 1979. Quality is Free. New York: McGraw-Hill

Daniel, W.W. 1978. Statistika Nonparametrik Terapan. Diterjemahkan oleh: Alex T.K.W. Jakarta: PT Gramedia. Terjemahan dari: Applied Nonparametric Statistics.

Garvin, D.A. 1984. What Does "Product Quality" Really Mean?. Sloan Management Review Article Hal 25-43.

Montgomery, D.C. 2013. Statistical Quality Control. Seventh Edition. United States of America: John Wiley.

Sujarweni, V.M., Endrayanto, P. 2012. Statistika untuk Penelitian. Yogyakarta: Graha Ilmu. 